\title{
Elevated level of carbon dioxide affects metabolism and shell formation in oysters Crassostrea virginica
}

\author{
Elia Beniash ${ }^{1, *}$, Anna Ivanina ${ }^{2}$, Nicholas S. Lieb ${ }^{1}$, Ilya Kurochkin ${ }^{2}$, Inna M. Sokolova ${ }^{2, *}$ \\ ${ }^{1}$ Department of Oral Biology, University of Pittsburgh, 589 Salk Hall, 3501 Terrace Street, Pittsburgh, Pennsylvania 15261, USA \\ ${ }^{2}$ Department of Biology, University of North Carolina at Charlotte, 9201 University City Blvd., Charlotte, \\ North Carolina 28223, USA
}

\begin{abstract}
Estuarine organisms are exposed to periodic strong fluctuations in seawater $\mathrm{pH}$ driven by biological carbon dioxide $\left(\mathrm{CO}_{2}\right)$ production, which may in the future be further exacerbated by the ocean acidification associated with the global rise in $\mathrm{CO}_{2}$. Calcium carbonate-producing marine species such as mollusks are expected to be vulnerable to acidification of estuarine waters, since elevated $\mathrm{CO}_{2}$ concentration and lower $\mathrm{pH}$ lead to a decrease in the degree of saturation of water with respect to calcium carbonate, potentially affecting biomineralization. Our study demonstrates that the increase in $\mathrm{CO}_{2}$ partial pressure $\left(\mathrm{pCO}_{2}\right)$ in seawater and associated decrease in $\mathrm{pH}$ within the environmentally relevant range for estuaries have negative effects on physiology, rates of shell deposition and mechanical properties of the shells of eastern oysters Crassostrea virginica (Gmelin). High $\mathrm{CO}_{2}$ levels $\left(\mathrm{pH} \sim 7.5, \mathrm{pCO}_{2} \sim 3500 \mu \mathrm{atm}\right)$ caused significant increases in juvenile mortality rates and inhibited both shell and soft-body growth compared to the control conditions ( $\mathrm{pH} \sim 8.2, \mathrm{pCO}_{2}$ $\sim 380 \mu \mathrm{atm})$. Furthermore, elevated $\mathrm{CO}_{2}$ concentrations resulted in higher standard metabolic rates in oyster juveniles, likely due to the higher energy cost of homeostasis. The high $\mathrm{CO}_{2}$ conditions also led to changes in the ultrastructure and mechanical properties of shells, including increased thickness of the calcite laths within the hypostracum and reduced hardness and fracture toughness of the shells, indicating that elevated $\mathrm{CO}_{2}$ levels have negative effects on the biomineralization process. These data strongly suggest that the rise in $\mathrm{CO}_{2}$ can impact physiology and biomineralization in marine calcifiers such as eastern oysters, threatening their survival and potentially leading to profound ecological and economic impacts in estuarine ecosystems.
\end{abstract}

KEY WORDS: Hypercapnia - Ocean acidification · Calcification · Shell structure · Energy metabolism · Oxygen consumption $\cdot$ Mollusks

\section{INTRODUCTION}

Estuarine ecosystems are areas of high biological diversity and productivity that are normally exposed to a high degree of natural and anthropogenic stress including pollution, fluctuations in temperature, salinity, dissolved oxygen $\left(\mathrm{O}_{2}\right)$ and carbon dioxide $\left(\mathrm{CO}_{2}\right)$ levels, and water $\mathrm{pH}$. Among these stressors, environmental hypercapnia (elevated $\mathrm{CO}_{2}$ levels) and associated acidification of the seawater play an important yet currently not well understood role. Although seawater has substantial buffering capacity, variation in seawater chemistry due to factors such as hypercapnia caused by biological activity, freshwater inputs, and run-off from acidic soils leads to substantial shifts of seawater $\mathrm{pH}$ in estuaries. In estuaries, $\mathrm{pH}$ can vary on a daily and seasonal basis from the values typical for the open ocean ( 7.8 to 8.2 ) down to $\mathrm{pH} 6.0$ to 7.0 (Cochran \& Burnett 1996, Hubertz \& Cahoon 1999, Keppler \& Ringwood 2002), and periods of low $\mathrm{pH}$, typically associated with elevated $\mathrm{CO}_{2}$ levels, may persist in some estuaries for a prolonged period of time, up to 
between 4 and 5 mo in summer and early fall (Cochran \& Burnett 1996, Keppler \& Ringwood 2002; see also long-term water $\mathrm{pH}$ data for eastern US estuaries at http://cdmo.baruch.sc.edu/). Given that $\mathrm{pH}$ is measured on a log scale, even relatively small changes in $\mathrm{pH}$ result in a considerable change in concentrations of hydrogen and hydroxide ions, which may have important physiological consequences for the resident biota.

The effects of seasonal and diurnal hypercapnia experienced by estuarine organisms are likely to become exacerbated in the coming years due to global climate change and ocean acidification driven by anthropogenically released $\mathrm{CO}_{2}$ (Caldeira \& Wickett 2003 , 2005). The uptake of atmospheric $\mathrm{CO}_{2}$ is especially pronounced in surface ocean waters $(<250 \mathrm{~m}$ depth), where nearly $50 \%$ of anthropogenic $\mathrm{CO}_{2}$ is absorbed, making near-shore habitats including estuaries vulnerable to ocean acidification (Feely et al. 2008, Doney et al. 2009). While photosynthetic autotrophs may benefit from mildly elevated $\mathrm{CO}_{2}$ levels, the combination of higher $\mathrm{CO}_{2}$ concentrations and lower $\mathrm{pH}$ in estuaries may have adverse effects on other marine organisms, ranging from shifts in acidbase homeostasis and changes in metabolic functions and energy balance, to negative impacts on biomineralization rates (Pörtner et al. 2004, 2005, Doney et al. 2009). Marine calcifiers (organisms with calcium carbonate, $\mathrm{CaCO}_{3}$, skeletons) are expected to be sensitive to $\mathrm{CO}_{2}$-driven changes in ocean chemistry, such as decrease in $\mathrm{pH}$ and the associated decline in $\mathrm{CaCO}_{3}$ saturation of seawater, although the direction and magnitude of the $\mathrm{CO}_{2}$-driven effects on calcification rates can significantly vary between species (Feely et al. 2004, Iglesias-Rodriguez et al. 2008, Clark et al. 2009, Ries et al. 2009). However, the complex effects of elevated $\mathrm{CO}_{2}$ on the physiology of these organisms are still poorly understood, hampering our ability to accurately predict the consequences of elevated $\mathrm{CO}_{2}$ on estuarine ecosystems.

Mollusks (Mollusca), the major group of marine calcifiers in estuarine and coastal waters, accumulate large amounts of carbonate in their shells. The shells are produced by specialized epithelial cells of the mantle with the assistance of $\mathrm{CaCO}_{3}$-transporting hemocytes (blood cells) (Wheller 1992, Mount et al. 2004). Bivalve shells consist of 3 major layers: the outermost proteinaceous layer called periostracum, and 2 mineralized layers called ostracum (middle layer) and hypostracum (inner layer), composed primarily of $\mathrm{CaCO}_{3}$ crystals (Wheller 1992). Shells protect mollusks from predators and parasites, and their mechanical properties such as fracture toughness are far superior to those of geological $\mathrm{CaCO}_{3}$ due to their unique structural organization and composition (Smith et al. 1999, Kamat et al. 2000). Shells also play a systemic role in the metabolism of mollusks, participating in the capture and deposition of respiratory $\mathrm{CO}_{2}$ in the shell mineral (Wilbur 1964, Wheller 1992) and in buffering of extracellular $\mathrm{pH}$ during environmental anaerobiosis (Crenshaw 1972, Sokolova et al. 2000b). An increase in the $\mathrm{CO}_{2}$ concentration in seawater and the associated reduction in the degree of saturation with respect to aragonite and calcite can impair shell deposition and increase shell dissolution rates, weakening the shells and affecting their functional properties in bivalves (Andersson et al. 2005, Orr et al. 2005, Gazeau et al. 2007, Kurihara et al. 2007, Kurihara 2008, Doney et al. 2009, Ries et al. 2009). Moreover, the energy costs of biomineralization may contribute to the basal metabolic costs of marine calcifiers, especially when $\mathrm{CaCO}_{3}$ is lost due to erosion in acidic seawater (Palmer 1992, Day et al. 2000, Wood et al. 2008). Thus, $\mathrm{CO}_{2}$-driven acidification of seawater may also have indirect negative impacts on mollusks by increasing basal metabolic costs and diverting energy from other processes such as growth or reproduction. Yet, the effects of hypercapnia and associated acidification of seawater on shell formation and properties as well as on basal metabolism in mollusks have not been extensively studied, and more research is critically needed to understand molluscan physiology and calcification under high $\mathrm{CO}_{2}$ conditions.

Eastern oysters Crassostrea virginica are common mollusks and major reef builders/ecosystem engineers in estuaries of the western Atlantic. They deposit large amounts of $\mathrm{CaCO}_{3}$ in their massive shells (nearly 90 to 1000 times more per year and unit area than most other mollusks) (Gutierrez et al. 2003). The shells of juvenile and adult $C$. virginica are made predominantly of lowmagnesium (Mg) calcite (Carter et al. 1998, Mount et al. 2004, Checa et al. 2007b, Esteban-Delgado et al. 2008). The shells are composed of an outer prismatic and an inner foliated layer. The foliated layer has a plywood-like structure which consists of roughly $200 \mathrm{~nm}$ thick mineral sheets called folia or laths, separated by an organic matrix (Sikes et al. 1998, Lee \& Choi 2007). Laths are composed of single crystals of calcite, with their $C$-axes tilted 20 to $30^{\circ}$ with respect to the shell surface normal, in the direction opposite to the direction of the shell growth, and with one of the faces forming the growing edges of laths (Checa et al. 2007a).

The relative simplicity of shell mineralogy of oysters simplifies interpretations of elevated $\mathrm{CO}_{2}$ levels on biomineralization and shell properties. Moreover, general metabolic physiology and biochemistry of oysters is well understood compared to other marine bivalves (Shumway 1982, Kennedy et al. 1996, Sokolova 2004, Kurochkin et al. 2009 and references therein), making them an attractive model for studies of physiological 
and metabolic effects of elevated $\mathrm{CO}_{2}$. The goals of the present study were to determine the effects of elevated $\mathrm{CO}_{2}$ levels on biomineralization and metabolic physiology of juvenile and adult Crassostrea virginica. We assessed growth, mineralogy, and structural organization in the shells in juvenile mollusks exposed to hypercapnic conditions; studied the effects of hypercapnia on basal metabolism and cellular energy status of juvenile and adult oysters; and compared the expression of 3 genes involved in calcification, i.e. carbonic anhydrase (CAn), voltage-dependent $\mathrm{Ca}^{2+}$ channel, and $\mathrm{H}^{+}$ATPase (Carre et al. 2006), under normoand hypercapnic conditions in adult C. virginica. The data presented here contribute to a better understanding of the potential impacts of environmental hypercapnia (such as is currently observed in many estuaries of the southeastern USA) as well as ocean acidification in estuaries on this key group of marine calcifiers.

\section{MATERIALS AND METHODS}

Animal maintenance and experimental exposures. Juvenile (3 wk post-metamorphosis, <1 mm shell length) and adult Crassostrea virginica (age $>2 \mathrm{yr}, 8$ to $12 \mathrm{~cm}$ shell length) were obtained from commercial oyster suppliers (J \& B Aquafood and Taylor Shellfish Farms for juveniles and adults, respectively). The oysters were acclimated for 5 to $7 \mathrm{~d}$ at $20^{\circ} \mathrm{C}$ and a salinity of 30 in re-circulating water tanks with artificial seawater (ASW; Instant Ocean ${ }^{\circledR}$, Kent Marine) prior to experimentation.

For hypercapnic treatments, $\mathrm{CO}_{2}$-enriched air was vigorously bubbled through the seawater using certified gas mixtures containing $0.5 \% \mathrm{CO}_{2}, 21 \% \mathrm{O}_{2}$, and balance nitrogen (Roberts Oxygen). Gas content of the mixtures was analyzed by the manufacturer and certified to be accurate within $10 \%$ of the target value (Roberts Oxygen). The control (normocapnic) treatments were bubbled with ambient air. In both cases, gas flow through the seawater was adjusted in such a way that further increases in flow rate did not result in a $\mathrm{pH}$ change, indicating that experimental systems were at steady-state with respect to gas saturation. The steady-state $\mathrm{pCO}_{2}$ levels achieved in these treatments were $\sim 380$ and $\sim 3500 \mu$ atm for normocapnic and hypercapnic exposures, respectively (see Table 1 and 'Seawater parameters' below for more details).

Oysters were divided into 8 different batches $\left(\sim 50\right.$ juveniles or 5 adults batch $\left.^{-1}\right)$ and randomly assigned to either hypercapnic or normocapnic treatment. For each treatment, 4 replicate tanks (5 l) were set up, 2 of them containing 50 juveniles each, and 2 with 5 adults each. Water temperature was maintained at $21 \pm 1^{\circ} \mathrm{C}$ and salinity at $30 \pm 0.5$ in all tanks. Water was changed every other day. The experimental incubations were $20 \mathrm{wk}$ for juveniles and $2 \mathrm{wk}$ for adults. During the preliminary acclimation and experimental incubations, oysters were fed ad libitum every other day with a commercial algal blend ( $5 \mathrm{ml} \mathrm{tank}^{-1}$ ) containing Nannochloropsis oculata, Phaeodactylum tricornutum, and Chlorella sp. with a cell size of 2 to 20 $\mu \mathrm{m}$ (DT's Live Marine Phytoplankton). The feeding regime used higher algal concentrations than recommended by the manufacturer $\left(1 \mathrm{ml} \mathrm{l}^{-1}\right.$ vs. $0.4 \mathrm{ml} \mathrm{l}^{-1}$ every other day recommended by DT's Live Marine Phytoplankton); however, in our experience this higher feeding regime provides better results for long-term maintenance of good physiological condition of oysters (I. M. Sokolova unpubl. data). Algae were added to the tanks immediately following the water change.

In adults, no mortality was detected throughout the experiment. Due to their small size, juveniles' mortality could be determined only under a dissecting microscope. To minimize handling disturbance, mortality was assessed at the beginning of the experiment (to ensure that all animals were alive) and when the experiment was concluded.

Seawater parameters. Water $\mathrm{pH}$ was measured daily using a pH electrode ( $\mathrm{pH}$ meter Model 1671, Jenco Instruments) calibrated with National Institute of Standards and Technology (NIST) standard $\mathrm{pH}$ solutions (NBS standards). Due to the fact that longer equilibration times may be needed to stabilize the liquid junction potential of the electrode in high ionic-strength media such as seawater, the electrode was incubated for $1 \mathrm{~h}$ in seawater before the measurements. Seawater pH was stable throughout the experimental exposures, did not differ between the replicate tanks within normocapnic or hypercapnic exposures, and was $8.2 \pm 0.1$ and $7.5 \pm 0.1$ (mean \pm SD) in normocapnia and hypercapnia conditions, respectively $(\mathrm{n}=231$, repeatedmeasures ANOVA: $\mathrm{p}<0.05)$. These $\mathrm{pH}$ values are within the normal range currently found in estuaries, e.g. 7.4 to 8.2 for typical high-salinity sites (salinity 29 to 35) (Burnett 1997, Hubertz \& Cahoon 1999, Keppler \& Ringwood 2002). $\mathrm{O}_{2}$ levels in experimental tanks were periodically tested during the exposures using Clark-type oxygen probes (YSI 5331 Oxygen probe) connected to a YSI 5300A Biological Oxygen monitor, and ranged between 97 and $100 \%$ of air saturation throughout all exposures.

For water chemistry analysis, seawater samples were collected at the beginning, in the middle, and at the end of the experimental exposures in air-tight $50 \mathrm{ml}$ containers without air space to eliminate potential gas exchange, stabilized by mercuric chloride poisoning (Dickson et al. 2007) and immediately shipped to the Chesapeake Biological Laboratory (Solomons, MD) for analysis. Samples were kept in the dark at $+4^{\circ} \mathrm{C}$ during 
shipping and storage, and analyzed within a week of collection. Total dissolved inorganic carbon (DIC) concentrations were measured by Nutrient Analytical Services (Chesapeake Biological Laboratory) using a Shimadzu TOC5000 gas analyzer equipped with a nondispersive infrared sensor (NDIR) detector for $\mathrm{CO}_{2}$ determination (Shimadzu Scientific Instruments). Samples were measured immediately after opening to minimize gas exchange. Three to 5 replicates were run for each sample, and precision of the analysis was $1 \%$ or better for technical replicates from the same sample. Temperature, salinity, and $\mathrm{pH}$ were measured for each sample at the time of collection, and along with the total DIC levels were used to calculate $\mathrm{pCO}_{2}$, alkalinity, and the average degree of saturation $(\Omega)$ for calcite and aragonite in seawater using co2sys software (Pierrot et al. 2006). For co2sys settings, we used the NBS scale of seawater $\mathrm{pH}$, constants from Millero et al. (2006), and the $\mathrm{KSO}_{4}$ constant from Dickson (1990) (as implemented in Pierrot et al. 2006), and concentrations of silicate and phosphate for Instant Ocean ${ }^{\circledR}$ seawater ( 0.17 and $0.04 \mu \mathrm{mol} \mathrm{kg}{ }^{-1}$, respectively, at a salinity of 30). Water chemistry data for this subset of samples ( $\mathrm{n}=7$ to 14 ) are given in Table 1 ; temperature, salinity, and $\mathrm{pH}$ of this subset did not significantly differ from the remainder of the experimental seawater samples for which only temperature, salinity, and $\mathrm{pH}$ were measured (ANOVA: $\mathrm{p}>0.05$ ).

Whole-organism $\mathrm{O}_{2}$ consumption rates. $\mathrm{O}_{2}$ consumption rates $\left(\mathrm{MO}_{2}\right)$ were measured after $20 \mathrm{wk}$ and $2 \mathrm{wk}$ of normo- and hypercapnic exposure in juvenile and adult Crassostrea virginica, respectively. In juveniles, $\mathrm{MO}_{2}$ was determined by closed-system respirometry in $3 \mathrm{ml}$ water-jacketed chambers using
Clarke-type oxygen electrodes (Qubit Systems) at $20^{\circ} \mathrm{C}$ in ASW at a salinity of 30 and the same $\mathrm{CO}_{2}$ concentration as during experimental exposures. For each measurement, several similarly sized juveniles (2 to 8 , based on the individual size) were placed into the chamber and allowed to recover from the handling stress for at least $30 \mathrm{~min}$. The total wet mass of the batch was 17 to $90 \mathrm{mg}$, and the juveniles were selected in such a way that individual masses within each batch did not vary by more than $15 \%$. The chambers were then closed and $\mathrm{O}_{2}$ consumption of the juveniles was monitored for 20 to $30 \mathrm{~min}$. Decline in $\mathrm{O}_{2}$ concentration in the respirometry chambers was linear over this period, and $\mathrm{O}_{2}$ levels were never $<85 \%$ of air saturation. Respiration of each batch of juveniles was measured twice, with a brief (10 to $15 \mathrm{~min}$ ) recovery period in the open chamber between measurements, and data from the 2 replicates were averaged. Total wet body mass of juveniles was determined, and wet tissue mass was calculated from the total wet mass by subtracting the relative weight of the shell determined in the present study $(0.38$ and $0.22 \%$ of the total wet mass in juveniles exposed to normocapnia or hypercapnia, respectively, based on 'Shell and soft-tissue mass measurements' described below). Throughout this paper, juveniles exposed to normocapnia or hypercapnia are referred to as normocapnic or hypercapnic juveniles, respectively. After the $\mathrm{MO}_{2}$ determinations, all juvenile oysters were collected and stored in $70 \%$ ethanol until further analysis of body size and shell characteristics.

$\mathrm{O}_{2}$ consumption in adults was measured using Clark-type oxygen probes (YSI 5331 Oxygen probe) connected to a YSI 5300A Biological Oxygen monitor. Oysters were placed into a flowthrough respiration chamber and allowed to acclimate overnight. Water flow $\left(20 \mathrm{ml} \mathrm{min}^{-1}\right.$ ) was adjusted so that animals consumed $<25 \%$ of $\mathrm{O}_{2}$ at all times. $\mathrm{O}_{2}$ consumption was continuously monitored for 2 to $10 \mathrm{~h}$, using AcqKnowledge software (Biopac Systems) at $20^{\circ} \mathrm{C}$ in ASW at a salinity of 30 and the same $\mathrm{CO}_{2}$ concentration as during experimental exposures. Our pilot studies have shown that shortterm exposure to reduced $\mathrm{O}_{2}$ and elevated $\mathrm{CO}_{2}$ in closed or flow-through respirometry chambers has no effects on metabolic rates of oysters provided that $\mathrm{O}_{2}$ levels do not decline to $<75 \%$ of air saturation (data not shown). This is typical for most bivalves, including oysters (Shumway 1982, Le Moullac et al. 2007). After measurements, adult 
oysters were dissected and soft-tissue mass determined. Gill and mantle tissues were immediately shock-frozen in liquid nitrogen for further determination of mRNA expression and measurements of tissue metabolite concentration.

Respiration rates were corrected for the electrode drift, normalized to the average wet tissue mass of experimental oysters (1 $\mathrm{mg}$ and $10 \mathrm{~g}$ for juveniles and adults, respectively) as described elsewhere (Lannig et al. 2006) and expressed as $\mu \mathrm{mol} \mathrm{O}_{2} \mathrm{~h}^{-1} \mathrm{~g}^{-1}$ wet tissue mass. Calibration of oxygen electrodes, data acquisition, and $\mathrm{MO}_{2}$ calculations were performed as described in Sokolova (2004). $\mathrm{O}_{2}$ solubility of the seawater was $1.54 \mathrm{\mu mol} \mathrm{O}_{2} \mathrm{l}^{-1} \mathrm{Torr}^{-1}$ at $20^{\circ} \mathrm{C}$ and a salinity of 30 (Dejours 1975).

Shell and soft-tissue mass measurements. Each juvenile mollusk was given a unique code and placed in an individual container, flash-frozen, lyophilized, and stored in a desiccator at $-80^{\circ} \mathrm{C}$. The lyophilized mollusks were weighed individually using a microbalance XP 56 (Metler-Toledo) with a precision of $0.01 \mathrm{mg}$ or better to determine their total dry mass $\left(M_{t}\right)$. To determine the mass of the soft tissues, out of these liophylized and weighted mollusks 10 individuals with known $\mathrm{M}_{\mathrm{t}}\left(5 \operatorname{tank}^{-1}\right)$ were randomly selected from each treatment group. They were individually incubated in aqueous $2 \% \mathrm{Na}$ hypochlorite $(\mathrm{NaOCl})$ for $2 \mathrm{~min}$ to remove the soft tissues. Individual shells were briefly rinsed in large volumes of distilled deionized water (DDW), followed by a rinse in alcohol, freeze-dried, and weighed again to determine the mass of the shells $\left(M_{s h}\right)$. The shell mass was subtracted from the $M_{t}$ of the same individual to determine the dry mass of soft tissues $\left(\mathrm{M}_{\mathrm{st}}\right)$. Wet-tissue mass was calculated from the dry-tissue mass assuming $80 \%$ body water content determined in our earlier studies on Crassostrea virginica (data not shown).

To determine the projected shell area, juvenile oysters were placed in a Petri dish and their right (upper) shell valves were photographed under a dissecting microscope. The projected areas were calculated using the ImageJ 1.64 image processing package and expressed in $\mathrm{mm}^{2}$.

Shell mineral characterization using Fourier transform infrared (FTIR) spectroscopy. Ten individual juveniles (5 from each replicate tank) were collected from normocapnic and hypercapnic conditions after 20 wk of incubation. The soft tissue was removed as described above ('Shell and soft-tissue mass measurements') using $\mathrm{NaOCl}$. For FTIR spectroscopy we used total pulverized shells; however, because the size of the initial shells at the beginning of the experiments was very small $(<1 \mathrm{~mm})$, the fraction of the old shell in the total shell volume is minuscule. The shells were lyophilized, ground, and studied in the transmittance mode in $\mathrm{KBr}$ pellets using a Bruker Vertex 70 FTIR spectrometer. The $600-1000 \mathrm{~cm}^{-1}$ regions of the spectra were isolated, baseline-corrected, and normalized, and the $v_{2}$ and $v_{4}$ peak positions and heights were measured using the Spectrum 5.1 software package (Perkin-Elmer). The relative crystallinity of the shells was determined using the $v_{2}: v_{4}$ band intensity ratio (Beniash et al. 1997, Gueta et al. 2007, Chu et al. 2008).

Scanning electron microscopy (SEM) of shell structure. For SEM and micromechanical experiments (see 'Micromechanical tests of the shells' below), we used only the new portion of the juvenile shells grown during the laboratory exposures. The area of the new shell growth was clearly identifiable in juveniles due to the fact that the old shell grown in the field was darker in color and had a rougher surface than the new shell grown in the laboratory. The shells were prepared for SEM analysis and microhardness testing as described elsewhere (Bartlett et al. 2004, 2005, Baldassarri et al. 2008). Briefly, the lyophilized right valves of the shells of oyster juveniles were mounted and polymerized in epoxy resin (Epofix, ESM) at room temperature. The embedded shells were cut in the plane normal to the surface, which transects the shell from the acute apical tip to its most distal edge, using a slow-speed watercooled diamond saw (IsoMet, Buehler). The samples were then polished with Metadi diamond suspensions (Buehler), with the final diamond particle size of $0.25 \mu \mathrm{m}$ in DDW equilibrated with aragonite. Four samples per group were carbon-coated and analyzed using a Jeol 6330 SEM in the back-scattered electron mode (BSE SEM) as described elsewhere (Bartlett et al. 2004, 2005, Baldassarri et al. 2008). At least 4 micrographs were taken for each sample at a magnification of $15000 \times$, accelerating voltage set at $10000 \mathrm{kV}$ and 5 to $7 \mathrm{~mm}$ working distance. At this magnification, the field of view covered an area of $8 \times 6 \mu \mathrm{m}$. For each micrograph, the longest distance in the direction perpendicular to the direction of the laths was determined and divided by the number of laths in the field of view. The average lath thickness values in each sample was calculated based on data from the individual micrographs.

Micromechanical tests of the shells. The samples for microhardness tests were prepared the same way as for BSE SEM. Microhardness was determined using a standard Vickers hardness test. The samples were tested dry using a Leco microindenter equipped with a Vickers diamond indenter at $0.49 \mathrm{~N}$ load and $5 \mathrm{~s}$ dwelling time, and 10 to 15 indentations were acquired per sample. Values were averaged for each shell and expressed as Vickers hardness numbers. Three samples from each treatment group were tested. The fracture toughness $\left(\mathrm{K}_{\mathrm{c}}\right)$ was determined using Anstis' equation as previously described (Anstis et al. 1981, 
Baldassarri et al. 2008), with a Young's modulus value of $73 \mathrm{GPa}$ based on Lee et al. (2008). Indentations from 8 control shells and 10 hypercapnic shells were analyzed.

Expression of transcripts of biomineralizationrelated genes. Gene expression was determined in the distal edge of the mantle (along the edge of the normal shell growth) and gill tissue of adult Crassostrea virginica incubated for $2 \mathrm{wk}$ in hypercapnic or normocapnic seawater. Total RNA was extracted from the gill and mantle tissues using TRI Reagent (Sigma) according to the manufacturer's protocol. cDNA was obtained from 1 to $5 \mu \mathrm{g}$ total RNA using SuperScriptTM III reverse transcriptase (Invitrogen) according to the manufacturer's instruction. Expression of mRNA of $\mathrm{CA}$, voltage-dependent $\mathrm{Ca}^{2+}$ channel, and $\mathrm{H}^{+}$ATPase V-type subunit was measured by quantitative realtime PCR using a LightCycler ${ }^{\circledR} 2.0$ Real Time PCR System (Roche Applied Science) and the QuantiTect SYBR Green PCR kit (Qiagen) according to the manufacturers' instructions, and normalized against the expression for $\beta$-actin and an internal cDNA standard as described elsewhere (Pfaffl 2001, Sanni et al. 2008) (Table 2). A cDNA sample obtained from the gill tissue of a control adult oyster was used as internal standard in all analyses. Mantle is involved in shell formation in oysters; gills are not involved in biomineralization and were used as a reference tissue (Wheeler 1992).

Determination of metabolites. For the determination of tissue metabolite concentration, gills were quickly excised from adult oysters exposed for $2 \mathrm{wk}$ to hypercapnic or control conditions and immediately frozen in liquid nitrogen. Deproteinized tissue extracts were obtained using $0.6 \mathrm{~mol} \mathrm{l}^{-1}$ perchloric acid (PCA) with $150 \mathrm{mmol} \mathrm{l}^{-1}$ EDTA as described elsewhere (Sokolova et al. 2000a) and stored at $-80^{\circ} \mathrm{C}$. Concentrations of ATP, ADP, AMP, L-alanine, and acetate were mea- sured spectrophotometrically using standard enzymatic tests (Bergmeyer 1985).

Statistical analysis. Differences in the means for shell parameters, $\mathrm{MO}_{2}$, tissue metabolite levels, and levels of mRNA expression were tested using repeated-measures ANOVA with $\mathrm{CO}_{2}$ concentrations and tissue type (for mRNA expression) or $\mathrm{CO}_{2}$ concentrations only (for all other traits) as fixed factors, replicate exposure tanks as a random factor (block), and individual oyster samples as a repeated-measures variable within the block. Fisher's least significant difference (LSD) test was used for post hoc comparisons. Mortality of juveniles under different $\mathrm{CO}_{2}$ conditions was compared using a chi-square test. There were no significant differences in any of the studied parameters between the replicate tanks within each experimental condition. Statistical analyses were performed using SAS 8.2 software (SAS Institute). Differences were considered significant at $\mathrm{p}<0.05$ and marginally significant at $0.10<\mathrm{p} \leq 0.05$. Data are presented as mean \pm standard error of the mean unless otherwise indicated. For factor effects and their interactions in ANOVA, F-values with the corresponding degrees of freedom for the factor and error effects, as well as the probabilities of Type I error (p) are given. For post hoc pairwise comparisons, only p-values are presented.

\section{RESULTS}

\section{Effects of elevated $\mathrm{CO}_{2}$ on mortality and shell characteristics of juvenile oysters}

Hypercapnic exposure resulted in a significant increase of mortality in juvenile oysters (77\% vs. $46 \%$ in hypercapnia and normocapnia, respectively; $\mathrm{n}=89$ to $\left.98, \chi^{2}=18.4, p<0.0001\right)$. Average dry shell mass was

Table 2. Primer sequences used for quantitative PCR. Gene sequences for the target genes for Crassostrea virginica were obtained from the Marine Genomics database (www.marinegenomics.org, sequence accession nos. MGID94539, MGID95078, and MGID93334 for carbonic anhydrase, voltage-dependent $\mathrm{Ca}^{2+}$ channel, and $\mathrm{H}^{+}$ATPase V-type subunit, respectively), and the sequence for $\beta$-actin was obtained from GenBank (accession no. X75894.1). Annealing temperature used in PCR) ( $\mathrm{T}_{\text {ann }}$ ) was $55^{\circ} \mathrm{C}$ for all genes. PCR amplification efficiencies (E) were determined as described by Pfaffl (2001). FW: forward, RV: reverse

\begin{tabular}{|lllll|}
\hline Gene & Primer names & Primer sequence (5' to 3') & $\begin{array}{l}\text { Amplification } \\
\text { efficiency (E) }\end{array}$ \\
\hline Carbonic anhydrase & FW: CarbAnh-F23 & & AGA GGA ACA CCG TAT CGG AGC CA & $1.65 \pm 0.01$ \\
& RV: CarbAnh-R155 & ATG TCA ATG GGC GAC TGC CG & $(\mathrm{n}=4)$ \\
Voltage-dependent & FW: Cvir_CaChannel FW274 & TGC TGC TGA CAA ACT GAA CCA GTG & $1.99 \pm 0.13$ \\
Ca $^{2+}$ channel & RV: Cvir_CaChannel RV440 & TGG GGG AAG GCT GGA GTT TG & $(\mathrm{n}=4)$ \\
$\mathrm{H}^{+}$ATPase V-type & FW: Cvir_VacH+ATPase FW302 & GGA CTG GTC GTA GCT GCT GTC ATC & $2.13 \pm 0.14$ \\
subunit & RV: Cvir_VacH+ATPase RV471 & GGT TGT TGT GCC GTT CCA CG & $(\mathrm{n}=4)$ \\
$\beta$-actin & FW: Act-Cv-F437 & CAC AGC CGC TTC CTC ATC CTC C & $1.83 \pm 0.06$ \\
& RV: Act-Cv-R571 & CCG GCG GAT TCC ATA CCA AGG & $(\mathrm{n}=4)$ \\
\hline
\end{tabular}


$39 \%$ lower in hypercapnic juveniles compared to their normocapnic counterparts $(5.03 \pm 0.43 \mathrm{mg}$ vs. $8.28 \pm$ 0.69 mg; ANOVA: $\mathrm{p}=0.003, \mathrm{n}=10$; Fig. 1A). The average soft-tissue mass was also lower in juveniles exposed to hypercapnia $(0.04 \mathrm{mg})$ compared to controls $(0.16 \mathrm{mg})$ (ANOVA: $\mathrm{p}=0.04, \mathrm{n}=10$; Fig. 1B). In contrast, shell area did not differ between juveniles exposed to normocapnia and hypercapnia $\left(10.6 \pm 0.6\right.$ and $9.2 \pm 0.5 \mathrm{~mm}^{2}, \mathrm{n}=46$ and 22, respectively; ANOVA: $\mathrm{p}=0.087$ )

SEM ultrastructural analysis revealed that calcitic laths of the shells of juveniles from hypercapnic treatments were on average $227 \mathrm{~nm}$ thick, compared to $191 \mathrm{~nm}$ in the control shells (ANOVA: $\mathrm{p}=0.01, \mathrm{n}=4$; Fig. 1C). No other differences in shell structure were observed.

Vickers microhardness values of the juvenile shells tested in the direction parallel to the lath planes were higher in the normocapnic animals compared to the hypercapnic group (ANOVA: $249.1 \pm 8.0$ vs. $206.5 \pm 10.9$, $\mathrm{p}=0.04, \mathrm{n}=10$; Fig. 1D). Multiple long cracks formed around indentations in the shells of hypercapnic juvenile oysters, while only a few short cracks were observed in the shells from normocapnic juveniles, suggesting that the latter have higher fracture toughness $\left(\mathrm{K}_{\mathrm{C}}\right)$ (Fig. 2). $\mathrm{K}_{\mathrm{C}}$ analysis using Anstis' method revealed significant differences in fracture toughness between these groups. Fracture toughness of the shells was on average $0.49 \pm 0.09 \mathrm{MPa} \times \mathrm{m}^{0.5}$ and $0.20 \pm 0.02 \mathrm{MPa} \times$ $\mathrm{m}^{0.5}$ in juveniles exposed to normocapnia and hypercapnia, respectively (ANOVA: $\mathrm{p}=0.02, \mathrm{n}=8$ to 10 ).
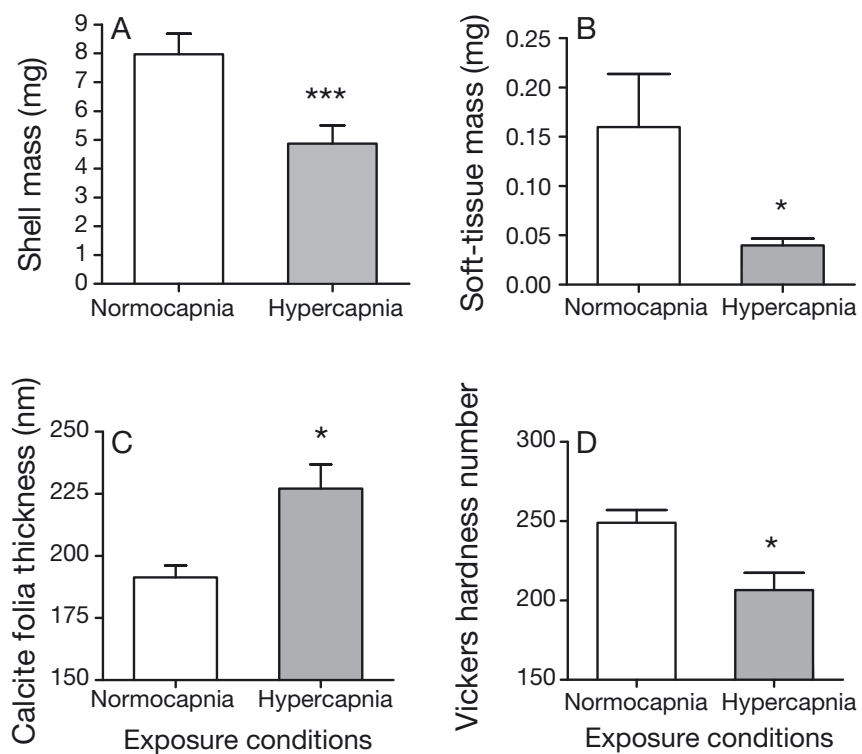

Fig. 1. Crassostrea virginica. Effects of hypercapnic exposure on (A) dry shell mass $(\mathrm{n}=10)$, (B) dry mass of soft tissues $(\mathrm{n}=$ 10), (C) average thickness of calcite laths in the shell $(n=4)$, and (D) shell microhardness $(\mathrm{n}=4)$, in juveniles. ${ }^{*} \mathrm{p}<0.05$, ${ }^{* * *} \mathrm{p}<0.01$ (both vs. normocapnic controls)
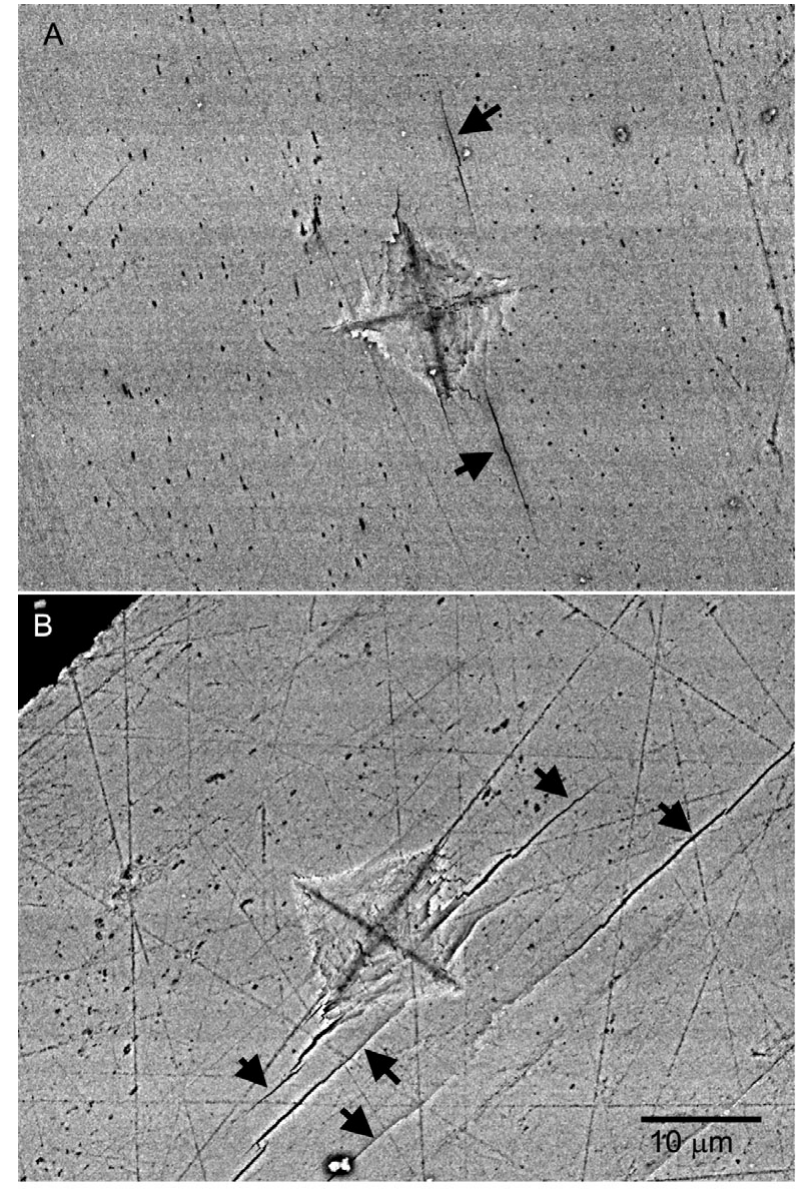

Fig. 2. Crassostrea virginica. Representative back-scattered electron mode scanning electron microscopy (BSE SEM) micrographs of the (A) normocapnic and (B) hypercapnic shells of juveniles indented with a Vickers tip under a $25 \mathrm{~N}$ load. Note that the fracture damage to the hypercapnic shell is much more severe (arrows)

The analysis of the FTIR spectra based on the positions of $v_{2}$ and $v_{4}$ peaks showed that shells of juveniles in both groups contained calcite; no other mineral phases were detected in the shells (Fig. 3, Table 3). The $v_{2}: v_{4}$ intensity ratio was used as a measure of the mineral crystallinity as described elsewhere (Beniash et al. 1997, Gueta et al. 2007, Chu et al. 2008). There was no significant difference in the $v_{2}: v_{4}$ intensity ratio between the 2 experimental groups $(3.9 \pm 0.04$ in normocapnic and $4.2 \pm 0.10$ in hypercapnic shells; ANOVA: $\mathrm{p}=0.28, \mathrm{n}=10$ ). However, these ratios were much higher than the ratio of 3.0 found in geological calcite, indicating that the juvenile oyster shell mineral is less crystalline. Interestingly, there was a small but significant difference in the position of the $v_{2}$ peak. In the shells from hypercapnic oysters it was slightly shifted towards a higher frequency, $877.6 \mathrm{~cm}^{-1}$, compared to $876.8 \mathrm{~cm}^{-1}$ in the normocapnic shells (2-tailed 

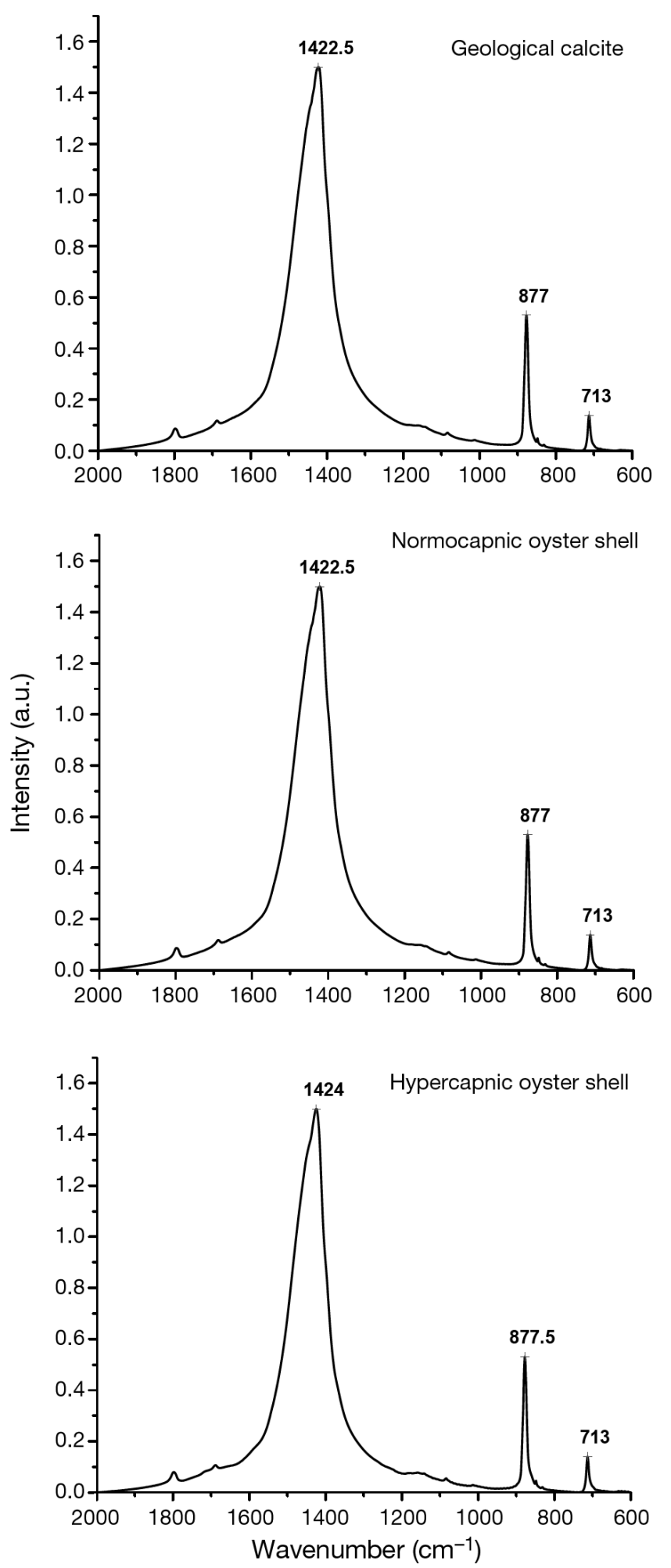

Fig. 3. Crassostrea virginica. Representative absorbance Fourier transform infrared (FTIR) spectra of geological calcite (top panel), and oyster shell calcite from a normocapnic juvenile oyster shell (middle panel) and a hypercapnic juvenile oyster shell (lower panel). Reference positions of $v_{2}$ and $v_{4}$ peaks in different calcium carbonate polymorphs are given in Table 3
Table 3. Positions of $v_{2}$ and $v_{4}$ peaks of major calcium carbonate polymorphs (after Chester \& Elderfield 1967, Beniash et al. 1997, Vagenas et al. 2003, Gueta et al. 2007). The reference positions of the $v_{2}$ and $v_{4}$ peaks on the Fourier transform infrared (FTIR) spectra were used for identification of the calcium carbonate polymorphs of juvenile oyster Crassostrea virginica shells, and the $v_{2}: v_{4}$ intensity ratio was used as a measure of the mineral crystallinity

\begin{tabular}{|c|c|c|}
\hline $\begin{array}{l}\text { Mineral } \\
\text { phase }\end{array}$ & $v_{4} \underset{\left(\mathrm{cm}^{-1}\right)}{\text { position }}$ & $\begin{array}{c}v_{2} \text { position } \\
\left(\mathrm{cm}^{-1}\right)\end{array}$ \\
\hline Calcite & $875-876$ & 713 \\
\hline Aragonite & 857 & Split peaks at 713 and 700 \\
\hline $\begin{array}{l}\text { Amorphous } \\
\text { calcium carbonat }\end{array}$ & te 866 & No peak \\
\hline
\end{tabular}

t-test: $\mathrm{p}<0.0001, \mathrm{n}=10$ ). This shift may indicate small differences in the structural organization of calcite crystals between normocapnic and hypercapnic shells.

\section{Effects of elevated $\mathrm{CO}_{2}$ on respiration rates and tissue energy status of juvenile and adult oysters}

In juveniles, hypercapnia induced a doubling of the standard metabolic rate (SMR) (ANOVA: $\mathrm{p}=0.003, \mathrm{n}=5$ to 12), whereas in adults there was a smaller nonsignificant increase by approximately $15 \%$ (Fig. 4). No difference in the levels of anaerobic end-products

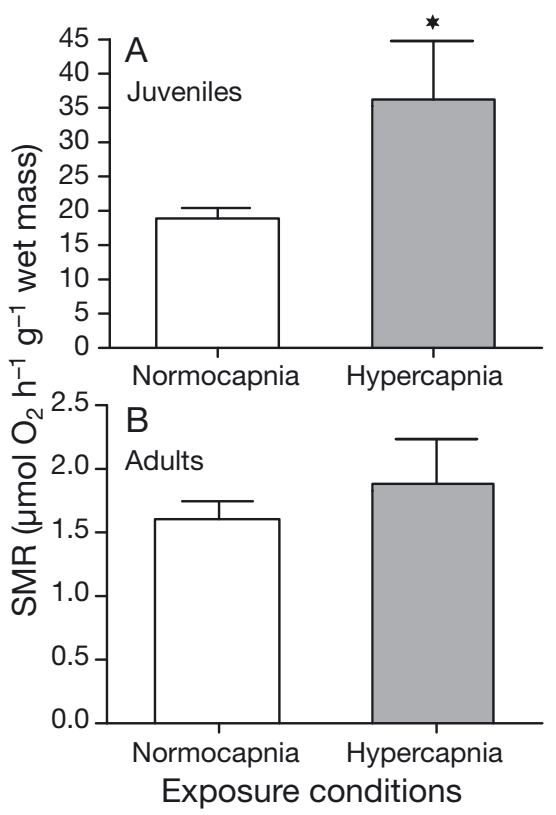

Fig. 4. Crassostrea virginica. Standard metabolic rates (SMR) of (A) juveniles and (B) adults exposed to different atmospheric $\mathrm{CO}_{2}$ levels. SMR was measured as oxygen consumption rate $\left(\mathrm{MO}_{2}\right)$ at $20^{\circ} \mathrm{C}$ and normalized for $1 \mathrm{mg}$ (juveniles) or $10 \mathrm{~g}$ (adults) soft-tissue mass. Differences in mass-specific $\mathrm{MO}_{2}$ between adults and juveniles reflect allometric effects on metabolism. ${ }^{*} \mathrm{p}<0.05$ (vs. normocapnic value). $\mathrm{n}=5$ to 12 
(L-alanine or acetate) was found between normocapnic and hypercapnic adult oysters (acetate: $0.16 \pm 0.04$ and $0.50 \pm 0.21 \mu^{-1} \mathrm{~mol} \mathrm{~g}^{-1}$; L-alanine: $8.44 \pm 0.63$ and $8.79 \pm$ $0.75 \mu \mathrm{mol} \mathrm{g}{ }^{-1}$ wet tissue mass, respectively; $\mathrm{n}=9$ to 10 , ANOVA: $p=0.16$ to 0.69 ). ADP levels were significantly higher in hypercapnic oysters $(0.26 \pm 0.03$ vs. $0.46 \pm 0.06$ in adults maintained in normocapnia and hypercapnia, respectively; ANOVA: $\mathrm{p}=0.02, \mathrm{n}=9$ to 10 ), whereas ATP and AMP levels did not significantly differ between the 2 groups ( $p=0.25$ and $0.26, n=9$ to 10 , respectively) (Fig. 5A). The ADP:ATP ratio was also higher in adult oysters exposed to high $\mathrm{CO}_{2}$ levels $(0.38 \pm 0.12$ vs. $0.25 \pm$ 0.03 in hypercapnia and normocapnia, respectively, $\mathrm{n}=$ 8 to 10); however, this difference was not statistically significant (ANOVA: $\mathrm{p}=0.26, \mathrm{n}=8$ to 10 ) due to the large variation in the hypercapnia-exposed group.

\section{Effects of $\mathrm{CO}_{2}$ on mRNA expression of biomineralization-related genes in adult oysters}

CA expression levels were significantly higher in the mantle compared to the gills of adult oysters exposed to normocapnia and hypercapnia (ANOVA: $F_{1,33}=$
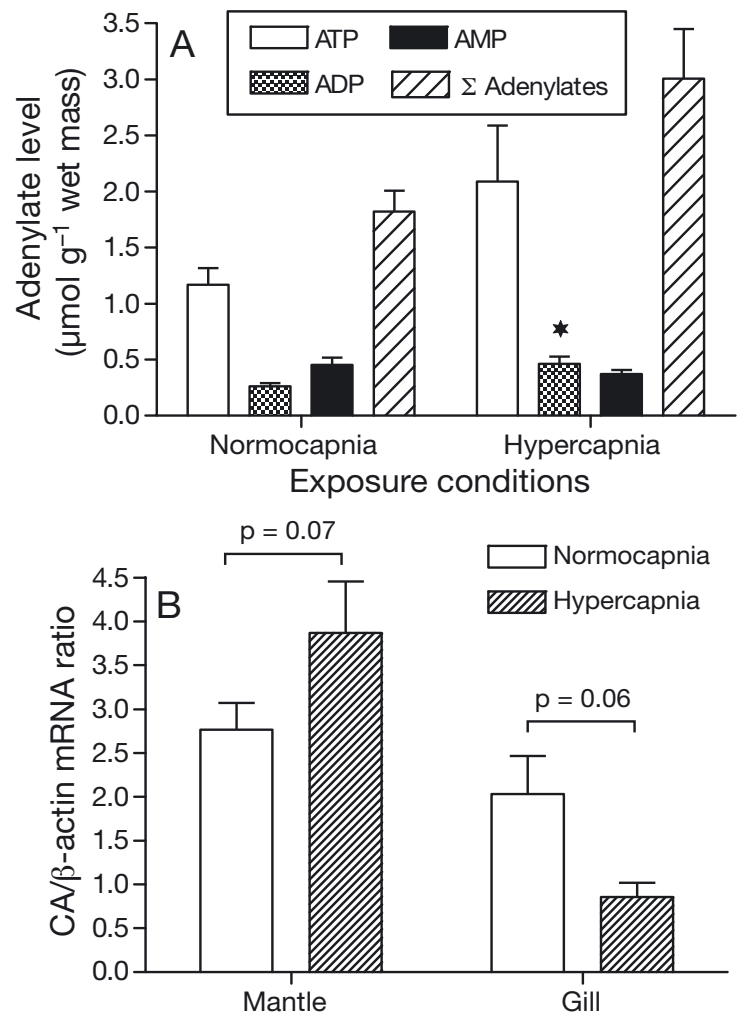

Fig. 5. Crassostrea virginica. Effects of different atmospheric $\mathrm{CO}_{2}$ levels on (A) levels of adenylates and (B) expression of carbonic anhydrase (CA) in adults. Adenylates were measured in gill tissues, and carbonic anhydrase mRNA expression in gills and mantle. ${ }^{*} \mathrm{p}<0.05$ (vs. normocapnic value). $\mathrm{n}=8$ to 10
20.08, $p=0.004$ for tissue effect) (Fig. 5B). The effects of hypercapnia on CA expression significantly differed between the 2 tissue types (ANOVA: $p=0.01$ for the interaction between tissue type and exposure conditions, $\mathrm{n}=8$ to 10 ) such that hypercapnic exposure resulted in an increase of CA mRNA expression in the mantle and a decline in the gills. Within each tissue type, this change was only marginally significant in the gills and in the mantle tissue (Fig. 5B). Expression levels of mRNA for $\mathrm{H}^{+}$ATPase were higher in the mantle $\left(\mathrm{H}^{+}\right.$ATPase to $\beta$-actin ratio: $0.37 \pm 0.03$ and $0.22 \pm 0.06$ in mantle and gills, respectively; ANOVA: $\mathrm{p}=0.0004$, $\mathrm{n}=8$ to 10 ) whereas the voltage-dependent $\mathrm{Ca}^{2+}$ channel mRNA was more highly expressed in the gills $\left(\mathrm{Ca}^{2+}\right.$ channel to $\beta$-actin ratio: $1.15 \pm 0.09$ and $1.50 \pm 0.23$ in mantle and gills, respectively; ANOVA: $\mathrm{p}=0.01, \mathrm{n}=8$ to 10). Neither of these 2 genes showed a difference in expression between normocapnic and hypercapnic conditions (ANOVA: $\mathrm{p}=0.75$ to $0.93, \mathrm{n}=8$ to 10 ).

\section{DISCUSSION}

\section{Effects of elevated $\mathrm{CO}_{2}$ on survival, growth, and metabolism}

Our results show that elevated $\mathrm{CO}_{2}$ levels have negative impacts on survival and somatic growth, as well as shell deposition rates and mechanical properties in juveniles of a model marine bivalve, Crassostrea virginica. Acidification of seawater to $\mathrm{pH}$ values between 7.4 and 7.6 , i.e. within the $\mathrm{pH}$ range found in estuarine habitats and which is typical for many estuaries in the southeastern USA in summer (Cochran \& Burnett 1996, Keppler \& Ringwood 2002; see also long-term water $\mathrm{pH}$ data for eastern US estuaries at http://cdmo.baruch. sc.edu/), was earlier shown to reduce viability of molluscan embryos and larvae (Kurihara et al. 2007, Kurihara 2008, Ellis et al. 2009, Talmage \& Gobler 2009), and the present study indicates that such acidification ( $\mathrm{pH}$ 7.5) also severely affects survivability of postmetamorphic stages (juveniles). High mortality was accompanied by a significant decrease in somatic growth rates in juvenile oysters under hypercapnic conditions, with a nearly 4 times lower soft body mass in juveniles maintained in hypercapnia. These results are in general agreement with recent literature reports of negative effects of elevated $\mathrm{CO}_{2}$ levels on survival and growth rates in mollusks (Gazeau et al. 2007, Beesley et al. 2008, Ellis et al. 2009) and other marine calcifiers (Kurihara 2008, Clark et al. 2009, Doney et al. 2009).

Remarkably, hypercapnic exposure resulted in elevated SMR in juveniles, and to a lesser extent in adult oysters, indicating higher costs of basal metabolism in a high $\mathrm{CO}_{2}$ environment. To date, few studies have 
determined the effects of hypercapnia on metabolic rates in marine calcifiers, including mollusks. In blue mussels Mytilus edulis, the oxygen consumption rate decreased after exposure to hypercapnic seawater at $\mathrm{pH} 7.3$ for $20 \mathrm{~h}$ (adults) or $90 \mathrm{~d}$ (juveniles) (Michaelidis et al. 2005). Studies in cephalopods showed a slight decrease (in jumbo squid Dosidicus gigas at $\mathrm{pH}$ 7.6; Rosa \& Seibel 2008) or no change (in cuttlefish Sepia officinalis at $\mathrm{pH} 7.1$; Gutowska et al. 2008) in SMR during short-term $(24 \mathrm{~h})$ exposure to hypercapnia. Interestingly, in the jumbo squid a hypercapnia-induced decrease in SMR was significant at elevated temperatures $\left(20\right.$ and $\left.25^{\circ} \mathrm{C}\right)$ but not at $10^{\circ} \mathrm{C}$, suggesting that in this species, hypercapnia induces metabolic depression only when combined with other stressors (Rosa \& Seibel 2008). Overall, the present and earlier studies suggest that metabolic response to hypercapnia in mollusks may be species-specific and depend on $\mathrm{CO}_{2}$ concentration and duration of exposure. In the present study, the hypercapnia-induced increase in SMR was associated with higher tissue ADP levels and elevated ADP:ATP ratios, likely supporting higher aerobic fluxes in oysters under high $\mathrm{CO}_{2}$ conditions. Notably, no accumulation of anaerobic end products (L-alanine or acetate) was observed during hypercapnic exposures, indicating that aerobic respiration was sufficient to cover the basal energy demand of the organism. The mechanisms by which hypercapnia affects the SMR levels are currently not known. Most likely, high $\mathrm{CO}_{2}$ affects different aspects of mollusk physiology, such as additional energy costs for acid-base regulation and compensatory increases in expression of biomineralization-related enzymes (e.g. CA). Irrespective of the exact mechanisms, elevated basal metabolic costs can divert energy from other essential ATP-requiring processes such as growth and reproduction (Calow 1989, Calow \& Forbes 1998) and thus may explain lower rates of somatic growth in hypercapnia-exposed juveniles. Interestingly, elevated seawater $\mathrm{pCO}_{2}$ (632 to 1480 uatm) has also been shown to delay metamorphosis in Crassostrea virginica larvae (Talmage \& Gobler 2009), consistent with the notion of the energy tradeoff between basal metabolism, and growth and development of oysters at high $\mathrm{CO}_{2}$ levels.

\section{Effects of elevated $\mathrm{CO}_{2}$ on juvenile shell deposition}

Exposure to high $\mathrm{CO}_{2}$ levels resulted in a substantial decrease in the rate of shell deposition in juvenile oysters, resulting in an approximately $40 \%$ decrease in shell mass in hypercapnic oysters. It is worth noting that this reduction in shell deposition rate was found despite the fact that the seawater remained saturated with respect to calcite $\left(\Omega_{\text {calcite }}=1.42\right.$ in hypercapnic exposures). A recent study also reported a decrease in the calcification rate of adult Crassostrea virginica with decreasing $\mathrm{CaCO}_{3}$ saturation state of seawater; this decrease was noticeable even before the seawater became undersaturated with respect to aragonite and calcite (Ries et al. 2009). Another study in C. virginica larvae reported a significant decrease in larval growth (measured as total length) at $\mathrm{pCO}_{2}$ of 632 and 1480 $\mu$ atm ( $\mathrm{pH}$ of 7.9 and 7.5 , respectively, at a salinity of 28) despite the fact that $\Omega_{\text {calcite }}$ remained above saturation (2.97 to 1.43) (Talmage \& Gobler 2009). Other changes in water chemistry (such as a decrease in salinity typical for many estuaries) may further depress the degree of $\mathrm{CaCO}_{3}$ saturation, thereby decreasing the driving force for shell deposition and increasing the shell dissolution rates. Interestingly, the average shell area was not affected by $\mathrm{CO}_{2}$ levels in the present study, suggesting that oysters were depositing thinner shells during the hypercapnic exposure. This contrasts with an earlier study of $C$. virginica larvae conducted in brackish estuarine waters (salinity of 18) under conditions undersaturated for aragonite where both the shell area and calcification rate were negatively affected by hypercapnia (Miller et al. 2009).

Overall, as discussed in 'Effects of elevated $\mathrm{CO}_{2}$ on survival, growth, and metabolism', a decrease in shell deposition in response to elevated $\mathrm{CO}_{2}$ levels appears to be a widespread phenomenon among marine bivalves. The mechanisms of this reduction are not fully understood. Two possible (not mutually exclusive) explanations can account for this decrease. First, a decrease in the degree of saturation of water with respect to $\mathrm{CaCO}_{3}$ at elevated $\mathrm{CO}_{2}$ concentrations can cause slower rates of mineral deposition and faster shell dissolution (Michaelidis et al. 2005). Second, slow shell growth may reflect an overall decrease in somatic growth due to the energy deficiency and a greater proportion of the organism's energy diverted from growth to basal maintenance, reflected in a higher SMR. Our data suggest that both of these mechanisms may contribute to reduced shell growth in oysters. Indeed, a 2fold increase in SMR and a 4 -fold reduction of the softtissue mass in hypercapnic juveniles suggest that bioenergetic mechanisms are implicated in the reduction of shell growth during hypercapnia. Moreover, because the shell is directly secreted by the mantle cells, a smaller soft-body size in hypercapnia-exposed individuals would lead to smaller shells. On the other hand, a trend towards an increase in CA expression in the mantle tissues of adult oysters in hypercapnia may suggest that oysters produce more CA (an enzyme which converts $\mathrm{CO}_{2}$ into bicarbonate and hence increases the driving force toward mineralization) to compensate for the changes in carbonate chemistry of extrapallial fluid. Future studies (outside the scope of 
the present work) will need to determine whether there is also an increase in enzymatic activity of CA in the mantle tissue in hypercapnic oysters.

\section{Effects of elevated $\mathrm{CO}_{2}$ on ultrastructure and mechanical properties of juvenile oyster shells}

The ultrastructure and mechanical properties of shells were significantly altered by high $\mathrm{CO}_{2}$, and no differences were found in the shell mineralogy between hypercapnic and normocapnic animals. Our observation of thicker mineral laths in the hypercapnic animals is intriguing. One might expect that a decrease in the degree of calcite saturation should slow the rate of mineral deposition, leading to the formation of thinner laths. In contrast, our results show an increase in lath thickness in hypercapnia. A possible explanation for this phenomenon could be a decrease in cell-division rates in mantle tissue (due to the overall decrease in the somatic growth rates) that leads to a slow-down in mantle growth and increase of the time interval for deposition of a single folium. However, at present this mechanism remains speculative and requires further investigation.

The foliated layer of Crassostrea virginica and other oyster species are multilayered nanomaterials, comprised of thin calcite laths bound together by the extracellular matrix molecules (Checa et al. 2007a, Lee et al. 2008). The mechanical properties of the shells are determined by the morphology and organization of crystalline laths and by the shell matrix component (Lee et al. 2008). Our results clearly show that the exposure of juvenile oysters to hypercapnia had a negative impact on the mechanical properties of their shells. Oyster shells formed in hypercapnic conditions demonstrated significantly lower hardness and fracture-toughness values. Given that the crystallinity of calcite did not change significantly in the hypercapnic shells, it is unlikely that the observed decrease in the mechanical strength of shells is associated with a change in the crystallographic characteristics of calcite mineral. More likely, it reflects changes in shell ultrastructure, such as the reported increase in the shell lath thickness. It has been shown that in multilayered nanomaterials, hardness and strength are inversely proportional to the thickness of the layers (Anderson \& Li 1995, He et al. 1997). This phenomenon of simultaneously increased toughness and hardness in the layered materials at the nanoscale is not fully understood. One possible explanation is that in a material with thinner layers, the cracks propagating during its deformation on average will travel shorter distances uninterrupted through the stiff and brittle crystalline layers and interface more often with softer organic rich lay- ers, which will deflect the cracks leading to more treacherous crack paths and hence toughening of the material (Fratzl et al. 2007, Zhang et al. 2010). Alternatively, lower hardness values of hypercapnic shells can be due to the alterations in the organic matrix (Lee et al. 2008); however, currently we do not have the data to support this hypothesis.

\section{Perspectives and significance}

Current models of ocean acidification predict a decline in seawater $\mathrm{pH}$ by 0.3 to 0.5 by the year 2100 and by 0.8 to 1.4 by the year 2300, depending on the $\mathrm{CO}_{2}$ emission scenario (Caldeira \& Wickett 2005). While the experimental conditions in the present study reflect extreme acidification, which is not expected to occur in the open ocean before the year 2300, and may never be reached under the more optimistic emission scenarios (Caldeira \& Wickett 2005), they are environmentally relevant to the present and the immediate future of estuaries. Currently, prolonged bouts of extreme hypercapnia associated with the reduction in seawater $\mathrm{pH}$ down to between 6 and 7.5 are typical for many estuaries, including oyster habitats in the southeastern USA (Pritchard 1967, Cochran \& Burnett 1996, Burnett 1997, Ringwood \& Keppler 2002). In some of these estuaries, low $\mathrm{pH}$ values ( 7 to 7.5 ) can persist for several months from late spring until early autumn (Cochran \& Burnett 1996, Ringwood \& Keppler 2002; see also seawater $\mathrm{pH}$ data for estuaries in the southeastern USA at http://cdmo.baruch.sc.edu/). Furthermore, Feely et al. (2008) have recently shown that the naturally occurring upwelling of $\mathrm{CO}_{2}$-enriched deep waters is amplified by the rise in atmospheric $\mathrm{CO}_{2}$, creating conditions in which vast coastal areas are exposed to acidified waters for prolonged periods of time. Given the complex dynamics of the carbonate system in estuarine and coastal waters, it is not yet fully understood to what degree global climate change and ocean acidification will affect carbonate chemistry in these areas, but it is likely that the global increase in $\mathrm{CO}_{2}$ may worsen the situation in many estuarine and coastal waters that already experience a wide range of $\mathrm{pH}$ fluctuations and acidification stress.

Overall, the results of the present study demonstrate that an increase in $\mathrm{CO}_{2}$ concentration negatively impacts eastern oysters in a number of ways. The hypercapnic exposure leads to higher mortality, slower body and shell growth rates, higher energy demands for basal maintenance, slightly elevated CA expression in the mantle, and lower hardness of the shells. Weakening of the shells reduces their protective properties and can make the mollusks more vulnerable to predators and parasites, reducing their chances for survival. 
These data demonstrate that the continuing rise in atmospheric $\mathrm{CO}_{2}$ can lead to negative impacts on mollusk populations similar to those earlier shown for other marine calcifiers such as corals (Anthony et al. 2008), especially in estuarine and coastal populations, which already experience a high degree of acidification and hypercapnic stress. Given the high degree of $\mathrm{pH}$ and $\mathrm{CO}_{2}$ stress already experienced by estuarine bivalves, their existing physiological adaptations may be insufficient to cope with the additional $\mathrm{CO}_{2}$ load on these ecosystems. Population decline of estuarine bivalves would lead to dramatic changes in ocean ecosystems on a global scale and could have a negative economic impact on coastal communities around the world.

Acknowledgments. This work was supported by funds provided by NSF award IOS-0951079 and North Carolina Sea Grant Minigrant (R/MG-0906) to I.M.S and E.B., and a UNC Charlotte Faculty Research Grant to I.M.S. We also thank 4 anonymous reviewers for their useful comments on an earlier version of this manuscript.

\section{LITERATURE CITED}

Anderson PM, Li C (1995) Hall-petch relations for multilayered materials. Nanostruct Mater 5:349-362

> Andersson AJ, Mackenzie FT, Lerman A (2005) Coastal ocean and carbonate systems in the high $\mathrm{CO}_{2}$ world of the anthropocene. Am J Sci 305:875-918

Anstis GR, Chantikul P, Lawn BR, Marshall DB (1981) A critical evaluation of indentation techniques for measuring fracture toughness: I. Direct crack measurements. J Am Ceram Soc 64:533-538

> Anthony KRN, Kline DI, Diaz-Pulido G, Dove S, Hoegh-Guldberg O (2008) Ocean acidification causes bleaching and productivity loss in coral reef builders. Proc Natl Acad Sci USA 105:17442-17446

Baldassarri M, Margolis HC, Beniash E (2008) Compositional determinants of mechanical properties of enamel. J Dent Res 87:645-649

Bartlett JD, Beniash E, Lee DH, Smith CE (2004) Decreased mineral content in MMP-20 null mouse enamel is prominent during the maturation stage. J Dent Res 83:909-913

Bartlett JD, Dwyer SE, Beniash E, Skobe Z, Payne-Ferreira TL (2005) Fluorosis: a new model and new insights. J Dent Res 84:832-836

Beesley A, Lowe DM, Pascoe CK, Widdicombe S (2008) Effects of $\mathrm{CO}_{2}$-induced seawater acidification on the health of Mytilus edulis. Clim Res 37:215-225

Beniash E, Aizenberg J, Addadi L, Weiner S (1997) Amorphous calcium carbonate transforms into calcite during sea urchin larval spicule growth. Proc R Soc Lond B Biol Sci 264:461-465

Bergmeyer HU (1985) Methods of enzymatic analysis. Vol VI. Metabolites 1: carbohydrates. Vol VIII. Metabolites 3: lipids, amino acids and related compounds. VCH Verlagsgesellschaft, Weinheim

Burnett LE (1997) The challenges of living in hypoxic and hypercapnic aquatic environments. Am Zool 37:633-640

Caldeira K, Wickett ME (2003) Oceanography: anthropogenic carbon and ocean $\mathrm{pH}$. Nature 425:365

Caldeira K, Wickett ME (2005) Ocean model predictions of chemistry changes from carbon dioxide emissions to the atmosphere and ocean. J Geophys Res Oceans 110: C09S04 doi:10.1029/2004JC002671

- Calow P (1989) Proximate and ultimate responses to stress in biological systems. Biol J Linn Soc 37:173-181

Calow P, Forbes VE (1998) How do physiological responses to stress translate into ecological and evolutionary processes? Comp Biochem Physiol A 120:11-16

Carre M, Bentaleb I, Bruguier O, Ordinola E, Barrett NT, Fontugne M (2006) Calcification rate influence on trace element concentrations in aragonitic bivalve shells: evidences and mechanisms. Geochim Cosmochim Acta 70: 4906-4920

Carter JG, Barrera E, Tevesz MJS (1998) Thermal potentiation and mineralogical evolution in the Bivalvia (mollusca). J Paleontol 72:991-1010

Checa AG, Esteban-Delgado FJ, Rodriguez-Navarro AB (2007a) Crystallographic structure of the foliated calcite of bivalves. J Struct Biol 157:393-402

Checa AG, Jimenez-Lopez C, Rodriguez-Navarro A, Machado $\mathrm{J}$ (2007b) Precipitation of aragonite by calcitic bivalves in Mg-enriched marine waters. Mar Biol 150:819-827

> Chester R, Elderfield H (1967) The application of infra-red absorption spectroscopy to carbonate mineralogy. Sedimentology 9:5-21

> Chu V, Regev L, Weiner S, Boaretto E (2008) Differentiating between anthropogenic calcite in plaster, ash and natural calcite using infrared spectroscopy: implications in archaeology. J Archaeol Sci 35:905-911

> Clark D, Lamare M, Barker M (2009) Response of sea urchin pluteus larvae (Echinodermata: Echinoidea) to reduced seawater $\mathrm{pH}$ : a comparison among a tropical, temperate, and a polar species. Mar Biol 156:1125-1137

Cochran RE, Burnett LE (1996) Respiratory responses of the salt marsh animals, Fundulus heteroclitus, Leiostomus xanthurus, and Palaemonetes pugio to environmental hypoxia and hypercapnia and to the organophosphate pesticide, azinphosmethyl. J Exp Mar Biol Ecol 195: 125-144

Crenshaw MA (1972) The inorganic composition of molluscan extrapallial fluid. Biol Bull 143:506-512

> Day EG, Branch GM, Viljoen C (2000) How costly is molluscan shell erosion? A comparison of two patellid limpets with contrasting shell structures. J Exp Mar Biol Ecol 243:185-208

Dejours P (1975) Principles of comparative respiratory physiology. Elsevier/North Holland Press, New York, NY

Dickson AG (1990) Standard potential of the reaction: $\mathrm{AgCl}(\mathrm{s})$ $+1 / 2 \mathrm{H}_{2}(\mathrm{~g})=\mathrm{Ag}(\mathrm{s})+\mathrm{HCl}(\mathrm{aq})$, and the constant of the ion $\mathrm{HSO}_{4}^{-}$in synthetic sea water from 273.15 to $318.15 \mathrm{~K}$. J Chem Thermodyn 22:113-127

Dickson AG, Sabine CL, Christian JR (eds) (2007) Guide to best practices for ocean $\mathrm{CO}_{2}$ measurements. PICES Spec Publ 3

Doney SC, Fabry VJ, Feely RA, Kleypas JA (2009) Ocean acidification: the other $\mathrm{CO}_{2}$ problem. Annu Rev Mar Sci $1: 169-192$

> Ellis RP, Bersey J, Rundle SD, Hall-Spencer JM, Spicer JI (2009) Subtle but significant effects of CO2 acidified seawater on embryos of the intertidal snail, Littorina obtusata. Aquat Biol 5:41-48

> Esteban-Delgado FJ, Harper EM, Checa AG, RodriguezNavarro AB (2008) Origin and expansion of foliated microstructure in pteriomorph bivalves. Biol Bull 214: 153-165

Feely RA, Sabine CL, Lee K, Berelson W, Kleypas J, Fabry VJ, Millero FJ (2004) Impact of anthropogenic $\mathrm{CO}_{2}$ on the $\mathrm{CaCO}_{3}$ system in the oceans. Science 305:362-366 
Feely RA, Sabine CL, Hernandez-Ayon JM, Ianson D, Hales B (2008) Evidence for upwelling of corrosive 'acidified' water onto the continental shelf. Science 320:1490-1492

Fratzl P, Gupta HS, Fischer FD, Kolednik O (2007) Hindered crack propagation in materials with periodically varying Young's modulus - lessons from biological materials. Adv Mater 19:2657-2661

Gazeau F, Quiblier C, Jansen JM, Gattuso JP, Middelburg JJ, Heip CHR (2007) Impact of elevated $\mathrm{CO}_{2}$ on shellfish calcification. Geophys Res Lett 34:L07603 doi:10.1029/ 2006GL028554

> Gueta R, Natan A, Addadi L, Weiner S, Refson K, Kronik L (2007) Local atomic order and infrared spectra of biogenic calcite. Angew Chem Int Ed 46:291-294

Gutierrez JL, Jones CG, Strayer DL, Iribarne OO (2003) Mollusks as ecosystem engineers: the role of shell production in aquatic habitats. Oikos 101:79-90

Gutowska MA, Pörtner HO, Melzner F (2008) Growth and calcification in the cephalopod Sepia officinalis under elevated seawater $\mathrm{pCO}_{2}$. Mar Ecol Prog Ser 373:303-309

He JL, Li WZ, Li HD (1997) Simulation of nacre with TiN/Pt multilayers and a study of their hardness. J Mater Res $12: 3140-3145$

Hubertz E, Cahoon L (1999) Short-term variability of water quality parameters in two shallow estuaries of North Carolina. Estuaries Coasts 22:814-823

Iglesias-Rodriguez MD, Halloran PR, Gittins JR, Green DRH and others (2008) Phytoplankton calcification in a high$\mathrm{CO}_{2}$ world. Science 320:336-340

Kamat S, Su X, Ballarini R, Heuer AH (2000) Structural basis for the fracture toughness of the shell of the conch Strombus gigas. Nature 405:1036-1040

Kennedy VS, Newell RIE, Eble AF (eds) (1996) The eastern oyster Crassostrea virginica. Maryland Sea Grant, College Park, MD

Keppler CJ, Ringwood AH (2002) Effects of metal exposures on juvenile clams, Mercenaria mercenaria. Bull Environ Contam Toxicol 68:43-48

Kurihara $\mathrm{H}$ (2008) Effects of $\mathrm{CO}_{2}$-driven ocean acidification on the early developmental stages of invertebrates. Mar Ecol Prog Ser 373:275-284

Kurihara H, Kato S, Ishimatsu A (2007) Effects of increased seawater $\mathrm{pCO}_{2}$ on early development of the oyster Crassostrea gigas. Aquat Biol 1:91-98

Kurochkin IO, Ivanina AV, Eilers S, Downs CA, May LA, Sokolova IM (2009) Cadmium affects metabolic responses to prolonged anoxia and reoxygenation in eastern oysters Crassostrea virginica. Am J Physiol Regul Integr Comp Physiol 297:R1262-R1272

Lannig G, Flores JF, Sokolova IM (2006) Temperature-dependent stress response in oysters, Crassostrea virginica: pollution reduces temperature tolerance in oysters. Aquat Toxicol 79:278-287

> Le Moullac G, Queau I, Le Souchu P, Pouvreau S, Moal J, Le Coz JR, Damain JF (2007) Metabolic adjustments in the oyster Crassostrea gigas according to oxygen level and temperature. Mar Biol Res 3:357-366

Lee SW, Choi CS (2007) The correlation between organic matrices and biominerals (myostracal prism and folia) of the adult oyster shell, Crassostrea gigas. Micron 38:58-64

Lee SW, Kim GH, Choi CS (2008) Characteristic crystal orientation of folia in oyster shell, Crassostrea gigas. Mater Sci Eng C 28:258-263

> Michaelidis B, Ouzounis C, Paleras A, Pörtner HO (2005) Effects of long-term moderate hypercapnia on acid-base balance and growth rate in marine mussels Mytilus galloprovincialis. Mar Ecol Prog Ser 293:109-118
Miller AW, Reynolds AC, Sobrino C, Riedel GF (2009) Shellfish face uncertain future in high $\mathrm{CO}_{2}$ world: influence of acidification on oyster larvae calcification and growth in estuaries. PLoS ONE 4:e5661

Millero FJ, Graham TB, Huang F, Bustos-Serrano H, Pierrot D (2006) Dissociation constants of carbonic acid in seawater as a function of salinity and temperature. Mar Chem 100: 80-94

Mount AS, Wheeler AP, Paradkar RP, Snider D (2004) Hemocyte-mediated shell mineralization in the eastern oyster. Science 304:297-300

Orr JC, Fabry VJ, Aumont O, Bopp L and others (2005) Anthropogenic ocean acidification over the twenty-first century and its impact on calcifying organisms. Nature 437:681-686

Palmer AR (1992) Calcification in marine molluscs: How costly is it? Proc Natl Acad Sci USA 89:1379-1382

Pfaffl MW (2001) A new mathematical model for relative quantification in real-time RT-PCR. Nucleic Acids Res 29: 2002-2007

Pörtner HO, Langenbuch M, Reipschlager A (2004) Biological impact of elevated ocean $\mathrm{CO}_{2}$ concentrations: lessons from animal physiology and earth history. J Oceanogr 60: 705-718

Pierrot D, Lewis E, Wallace DWR (2006) MS Excel program developed for $\mathrm{CO}_{2}$ System Calculations. ORNL/CDIAC105a. Carbon Dioxide Information Analysis Center, Oak Ridge National Laboratory, US Department of Energy, Oak Ridge, TN

Pörtner HO, Langenbuch M, Michaelidis B (2005) Synergistic effects of temperature extremes, hypoxia, and increases in $\mathrm{CO}_{2}$ on marine animals: from earth history to global change. J Geophys Res Oceans 110:C09S10 doi:10.1029/ 2004JC002561

Pritchard DW (1967) What is an estuary: physical viewpoint. In: Lauff GH (ed) Estuaries. American Association for the Advancement of Science, Washington, DC, p 3-5

$>$ Ries JB, Cohen AL, McCorkle DC (2009) Marine calcifiers exhibit mixed responses to $\mathrm{CO}_{2}$-induced ocean acidification. Geology 37:1131-1134

$>$ Ringwood AH, Keppler CJ (2002) Water quality variation and clam growth: Is $\mathrm{pH}$ really a non-issue in estuaries? Estuaries 25:901-907

Rosa R, Seibel BA (2008) Synergistic effects of climate-related variables suggest future physiological impairment in a top oceanic predator. Proc Natl Acad Sci USA 105: 20776-20780

> Sanni B, Williams K, Sokolov EP, Sokolova IM (2008) Effects of acclimation temperature and cadmium exposure on mitochondrial aconitase and LON protease from a model marine ectotherm, Crassostrea virginica. Comp Biochem Physiol C 147:101-112

Shumway SE (1982) Oxygen consumption in oysters: an overview. Mar Biol Lett 3:1-23

Sikes CS, Wheeler AP, Wierzbicki A, Dillaman RM, De Luca L (1998) Oyster shell protein and atomic force microscopy of oyster shell folia. Biol Bull 194:304-316

Smith BL, Schaffer TE, Viani M, Thompson JB and others (1999) Molecular mechanistic origin of the toughness of natural adhesives, fibres and composites. Nature 399: 761-763

Sokolova IM (2004) Cadmium effects on mitochondrial function are enhanced by elevated temperatures in a marine poikilotherm, Crassostrea virginica Gmelin (Bivalvia: Ostreidae). J Exp Biol 207:2639-2648

> Sokolova IM, Bock C, Pörtner HO (2000a) Resistance to freshwater exposure in White Sea Littorina spp. I. Anaerobic 
metabolism and energetics. J Comp Physiol B 170:91-103

Sokolova IM, Bock C, Pörtner HO (2000b) Resistance to freshwater exposure in White Sea Littorina spp. II. Acid-base regulation. J Comp Physiol B 170:105-115

Talmage SC, Gobler CJ (2009) The effects of elevated carbon dioxide concentrations on the metamorphosis, size, and survival of larval hard clams (Mercenaria mercenaria), bay scallops (Argopecten irradians), and Eastern oysters (Crassostrea virginica). Limnol Oceanogr 54:2072-2080

- Vagenas NV, Gatsouli A, Kontoyannis CG (2003) Quantitative analysis of synthetic calcium carbonate polymorphs using FT-IR spectroscopy. Talanta 59:831-836

Editorial responsibility: Gretchen Hofmann, Santa Barbara, California, USA
Wheeler AP (1992) Mechanisms of molluscan shell formation. In: Bonucci E (ed) Calcification in biological systems. CRC Press, Boca Raton, FL, p 179-215

Wilbur KM (1964) Shell formation and regeneration. In: Wilbur KM, Yonge CM (eds) Physiology of Mollusca. Academic Press, New York, NY, p 243

Wood HL, Spicer JI, Widdicombe S (2008) Ocean acidification may increase calcification rates, but at a cost. Proc R Soc Lond B Biol Sci 275:1767-1773

Zhang JY, Liu G, Zhang X, Zhang GJ, Sun J, Ma E (2010) A maximum in ductility and fracture toughness in nanostructured $\mathrm{Cu} / \mathrm{Cr}$ multilayer films. Scripta Mater 62: 333-336

Submitted: January 19, 2010; Accepted: September 23, 2010 Proofs received from author(s): November 23, 2010 